\title{
Paradigm of Customer Relationship Management and its Various Perspectives
}

\author{
Apeksha Jain ${ }^{1}$, Manoj Kumar Sharma ${ }^{2}$ \\ ${ }^{I}$ (Research Scholar, Mewar University, India) \\ ${ }^{2}$ (Research Scholar, Mewar University, India)
}

\begin{abstract}
The research presented in this article demonstrates that the implementation of Customer Relationship Management (CRM) activities seems to be beneficial in building a good image of the organization in the eyes of customers by making them psychologically satisfied. In today's competitive scenario it becomes crucial for firms and specially the service organization's to implement CRM Approach to build up a loyal customer base. The purpose of this research was to increase knowledge and understanding the concept of CRM and its various perspectives. The contribution of this article is to show that what the CRM is and how this approach works for benefiting both customer and organizations.
\end{abstract}

Keywords - Customer Relationship Management, Implementation, Knowledge, Loyal, Perspectives.

\section{CRM as an Emerging Paradigm}

Relationship Marketing originated in early 1970s when the business units had a manifestation that it would be advisable to become 'customer emphatic' rather that 'product emphatic'. Birth of CRM was because of this heedful perceptiveness.

The famous writer and management consultant Peter Drucker wrote; 'The true business of every company is to make and keep customers'. Traditionally every transaction was on paper and dependent on goodwill which created hindrance in clutching customers. People used to work hard in entertaining customers by presenting new products with astonishing services; they were ready to work overtime for grasping more and more customers for increasing business. This too resulted in customer satisfaction and loyalty up to some extent, but at the end of the day there was no such bonding or relation between the two to carry on with future business smoothly (managementstudyguide.com, 2013).

According to Kanitwaranun, Chantaraskul, Waiyakarn, and Keokitichai (2010), in the past, business mindset was mainly product-oriented. Companies sold what they had and did not response customers so much. The concept was continued into the 1920s and manufacturers faced increased competition and companies started to focus on selling as the foundation of marketing initiative. Consequently, the paradigm was then moved to sales-oriented.

According to Raghuvanshi, Tripathi (2012), the primary reason for the emergence of CRM is the change in the marketing environment. Today marketing model is changing from the product-centered approach to customer-centered approach. Organization needs to create customized offers for customers and ensure relationship by providing better customer service and management of customer expectations. So, marketing should be devoted at enhancing customer relationships.

Kotler, Jain \& Maesincee (2002), stressed that one of the most important parts is value delivery and one of key strategies to do that is customer relationship management (CRM). CRM is absolutely mentioned as the critical part of many new marketing concepts.

Now to understand what actually this strategy is, let us go through some of its definitions and perspectives.

\section{CRM : Definitions and Various Perspectives}

Zablah, Beuenger, and Johnston (2003) suggest that CRM is "a philosophically-related offspring to relationship marketing which is for the most part neglected in the literature," and they conclude that "further exploration of CRM and its related phenomena is not only warranted but also desperately needed."

CRM can be defined from at least three perspectives: narrowly and tactically as a particular technology solution, wide-ranging technology, and customer centric. These perspectives can be portrayed as a continuum (Reinartz, Krafft, and Hoyer 2004).

According to Swift (2000), CRM provides enhanced opportunities to use data and information to both understand customers and co create value with them. This requires a cross-functional integration of processes, people, operations, and marketing capabilities that is enabled through information, technology, and applications. According to Gholami and Rahman (2012), four main enablers that play major role in business performance are people, technology, strategy, and process. The thought that dual creation of value is at the heart of CRM is moreover evident in all previous studies that examine the company-customer boundary. 


\section{Objectives of Customer Relationship Management}

CRM aims at focusing all the organizational activities towards creating and maintaining a customer. The process of developing a cooperative and collaborative relationship between the buyers and sellers is called customer relationship management. CRM is a new technique in marketing where the marketer tries to develop long term collaborative relationship with customers to develop them as life time customers. CRM aims to make the customer climb up the ladder of loyalty (Raghuvanshi, Tripathi 2012).

To understand it in a better way let us go through its various perspectives.

\section{CRM as a Tool for Relationship Marketing}

\section{Various Perspectives of CRM}

In the academic community, the terms "relationship marketing" and CRM are often used interchangeably (Parvatiyar and Sheth, 2001). However, CRM is more commonly used in the context of technology solutions and has been described as "information-enabled relationship marketing" (Ryals and Payne 2001).

According to Kotler, Keller, Koshy and Jha (2013), Relationship Marketing aims to build mutually satisfying long-term relationships with key constituents in order to earn and retain their business. No. of companies are shaping separate offers, services and messages to individual customers, based on information about past transactions, demographics and other factors.

Thus, CRM seems to be most lucrative approach for Retaining the existing customers and attracting the new customers.

2. CRM as One to One Marketing

According to Kotler, Keller, Koshy and Jha (2013), four step framework for one to one marketing that can be adapted to CRM marketing is as follows:

(i) Identify your prospects and customers- Don't go after everyone. Build, maintain and mine a rich customer database with information derived from all the channels and customer touch points.

(ii) Differentiate customers in terms of their needs and their value to your company- Spend proportionately more effort on the most valuable customers.

(iii) Interact with individual customers to improve your knowledge about their individual needs and to build stronger relationships- Formulate customized offerings that you can communicate in a personalized way.

(iv) Customize products, services and messages to each customer- Facilitate custom-company interaction through the company contact center and website.

\section{CRM as a Multichannel Integration Process}

The multichannel integration process is arguably one of the most important processes in CRM because it takes the outputs of the business strategy and value creation processes and translates them into value-adding activities with customers.

According to Raghuvanshi, Tripathi (2012), It has been viewed as a process aimed at collecting customer data, find profiles of customers and use the customer knowledge in specific marketing activities. It is a discipline which enables the companies to identify and target their most profitable customers.

\section{CRM as a Creator of Customer Value}

According to Kotler, Keller, Koshy and Jha (2013), Customer value can be created through the support of a holistic marketing orientation. One view of holistic marketing sees it as "integrating the value exploration, Value creation and value delivery activities with the purpose of building long term, mutually satisfying relationships. Holistic marketers achieve profitable growth by expanding customer share, building customer loyalty and capturing customer lifetime value. CRM allows the company to discover who its customers are, how they behave and what they need or want.

\section{CRM as a Strategic Perspective}

Grabner-Kraeuter and Moedritscher (2002) suggest that the absence of a strategic framework for CRM from which to define success is one reason for the disappointing results of many CRM initiatives. In any organization CRM strategy is a wide-ranging and detailed definition of the scope of the CRM programmed towards organizational goals. "The strategy is needed to keep businesses customer centric and to help the company constantly evolve internal processes and technology to acquire and retain customers."

CRM is fundamentally a strategy aligned with the superseding corporate strategy. It tries to attempts to optimize a firm's profitability, revenue and customer satisfaction by focusing on a customer centric process (Raghuvanshi, Tripathi 2012).

Thus in nutshell, CRM is the business strategy that aims to understand, anticipate, manage and personalize the needs of an organization's current and potential customers. At the heart of a perfect strategy is the creation of mutual value for all parties involved in the business process. 


\section{Conclusion}

Customer Relationship Management is very cost-effective. There is very less need of paper and manual work. The technologies used in implementing a CRM system are also available at very low price. All the details in CRM system related to customer databases are kept centralized. This reduces the process time and increases productivity. Satisfactory dealing with all the customers and providing them what they actually need increases the customer satisfaction. This enhances the business and thus increases the turnover and profits.

If the customer is satisfied they will always be loyal to you and customer retention is also a very important aspect rather than attracting the new customers. Installing a CRM system can definitely improve the situation and help in challenging the new ways of marketing and business in an efficient manner. Hence to fulfill the business needs every organization should be recommended to have a full-fledged CRM system.

\section{Journal Papers:}

\section{REFERENCES}

[1]. Gholami Saeed and Rahman Muhammad Sabbir (2012). CRM: A Conceptual Framework of Enablers and Perspectives. Business and Management Research, Vol. 1, No. 1; March 2012. Retrieved from www.sciedu.ca/bmr

[2]. Grabner-Kraeuter, S., \& Moedritscher, G. (2002, June). Alternative approaches toward measuring CRM performance. In Research Conference on Relationship Marketing and Customer Relationship Management (Vol. 6, Pp. 9-12).

[3]. Kanitwaranun Chaiwat, Chantaraskul Chomchin, Waiyakarn Somjate, Keokitichai Sindhchai (2010). The Empirical Implementation of Customer Relationship Management on Customer Satisfaction in Health Product Business: A Case of Small \& Medium Enterprise in Thailand.

[4]. Parvatiyar Atul \& Sheth Jagdish N. (2001). Customer Relationship Management: Emerging Practice, Process, and Discipline, Journal of Economic and Social Research 3(2) 2001, 2002 Preliminary Issue, 2

[5]. Raghuvanshi Dr. Richa, Rashmi Tripathi (2012) Customer Relationship Management as a Strategic Tool in the Indian Banking Sector: A Case Study of Axis Bank at Lucknow, National Conference on Emerging Challenges for Sustainable Business 2012.

[6]. Reinartz, W., Krafft, M., \& Hoyer, W. D. (2004). The customer relationship management process: Its measurement and impact on performance. Journal of marketing research, 293-305.

[7]. Rogers, M. (2005). Customer strategy: observations from the trenches. Journal of Marketing, 69(4), 262-263.

[8]. Ryals, L., \& Payne, A. (2001). Customer relationship management in financial services: towards information-enabled relationship marketing. Journal of Strategic Marketing, 9(1), 3-27.

[9]. Ryals, L., \& Knox, S. (2001). Cross-functional issues in the implementation of relationship marketing through customer relationship management. European Management Journal, 19(5), 534-542.

[10]. Zablah, A.R., Bellenger, D.N. and Johnston, W.J. (2004a) 'Customer relationship management implementation gaps', Journal of Personal Selling and Sales Management, Vol. 24, No. 4, pp.280-281.

Books:

[11]. Kotler Philip, Keller Kavin Lane, Koshy Abrham and Jha Mithileshwar (2012), Marketing Management, $13^{\text {th }}$ edition. Published by Pearson Education, pg-6,13,22,129.

[12]. Kotler, P., Jain, D. C., \& Maesincee, S.S. (2002) Marketing Moves: A New Approach to Profits, Growth, and Renewal.

[13]. Swift RS (2001). “Accelerating customer relationships: Using CRM and relationship technologies”, N.J., Upper saddle river, Prentice Hall Publisher.

Internet Link:

[14]. http://www.managementstudyguide.com/origin-of-crm.htm 